\title{
Impact of gasoline fuel emissions on Rhizopus stolonifer (Ehrenb.) Vuill. and Fusarium oxysporum (Schlecht.)
}

\author{
Kayode Peter Balogun, Abiola Titilola Aborisade* and Oluwole Olakunle Oladele
}

\begin{abstract}
Background: Alteration in the normal composition of gasses in the atmosphere referred to as air pollution can occur as a result of different processes, including emissions from vehicles and power generators. Gasses affect living things directly and indirectly by playing roles in respiration, membrane function, synthesis, and growth. The gasses contained in fumes emitted from vehicles and generators may likely have effect on microorganisms in the environment including microfungi. Two microfungi were selected to study the effect of generator emissions on their growth.

Results: The gaseous emissions from power generators fueled by gasoline caused reduction in spore germination and germ tube lengths of $R$. stolonifer and F. oxysporum. For the former, spore germination decreased with length of exposure after an initial increase by $\sim 100 \%$. The fungus exhibited a single major germination peak at 10 min and a minor one at 30-35 min exposures. Germ tube length of the fungus also decreased with increased exposure. $F$. oxysporum too showed reduced spore germination and germ tube length with exposure but the fungus seemed to adjust better to the unfavorable environment created by emitted gasses showing multiple peaks of reduced heights as time progressed, though another rise that could reach a peak appeared at the 45-min maximum exposure for germ tube length. The peaks were however more broad for spore germination experiments indicating more stability in adjustment than observed for germ tube length. Greatest reduction in spore germination was by $25 \%$ in $R$. stolonifer and $71 \%$ in F. oxysporum Germ tube length reduction for $R$. stolonifer was by $24-76 \%$, the greatest occurring at 35-min exposure, while for F. oxysporum it was $5-83 \%$, the greatest occurring at 40 min exposure.

Conclusions: These observations reveal the toxicity of the gasses emitted to the growth of the two filamentous fungi and the potential harmful effect to other fungi which might be useful in the ecosystem as decomposers and to those that may be pathogenic to higher plants.
\end{abstract}

Keywords: Fungi, Spore germination, Germ tube, Growth, Air pollutant, Gasoline emissions

\section{Background}

Fossil fuel emissions are a combination of hydrocarbons, oxides of carbon, nitrogen, and sulfur with particulate matter (Tavares et al. 2010). Emissions are released from wood and refuse burning, motor vehicles on roads, and power generators in homes, offices, small businesses,

*Correspondence: biolabo2000@yahoo.com

Department of Biology, The Federal University of Technology, PMB704, Akure, Nigeria

\section{Springer Open}

and big factories (Aliyu et al. 2019; Marais et al. 2014; Fagbeja et al. 2008; Osuji and Avwiri 2005). The major types of fuel used by vehicles and power generating sets are gasoline and diesel. The concentrations of the various gasses emitted during gasoline combustion depend partly on the condition of the engine. Water vapor is also produced when the fuel is efficiently combusted. All the gasses and droplets released into the atmosphere affect not only higher animals including man, but also
(0) The Author(s). 2020 Open Access This article is licensed under a Creative Commons Attribution 4.0 International License, which permits use, sharing, adaptation, distribution and reproduction in any medium or format, as long as you give appropriate credit to the original author(s) and the source, provide a link to the Creative Commons licence, and indicate if changes were made. The images or other third party material in this article are included in the article's Creative Commons licence, unless indicated otherwise in a credit line to the material. If material is not included in the article's Creative Commons licence and your intended use is not permitted by statutory regulation or exceeds the permitted use, you will need to obtain permission directly from the copyright holder. To view a copy of this licence, visit http://creativecommons.org/licenses/by/4.0/. 
plants (Darrall 2006; Winner and Greitner 2000) and most likely microorganisms in the environment. Many filamentous fungi are present in the environment as spores and hyphal fragments which can grow actively being involved in many processes affecting other organisms living or dead. Rhizopus stolonifer and Fusarium oxysporum are filamentous fungi found everywhere in air and soils and on plants causing wilts on stems, and rots on fruits and vegetables. The atmospheric compositions of gasses have direct and indirect effects on fungal metabolism and hence on their ability to grow.

Since the atmospheric composition of gasses is significantly altered by fuel combustion in cities partly as a result of pollution from motor vehicles and power generators (Marais et al. 2014), it is conceivable that this might also affect certain aspects of fungal physiology. It is therefore the reason that the effect of fuel emissions is presently being studied in relation to ability of some fungi to grow. Vehicular emissions cause more air pollution than generators (Aliyu et al. 2019) but for practical ease of testing microorganisms, the fumes from a generator will be employed to simulate the gasses from vehicle exhausts. Gas pollutants from both sources are similar (Marais et al. 2014) though their concentrations differ. Specifically, the spores of $R$. stolonifer and $F$. oxysporum both of which live saprophytically and pathogenically (Bautista-Banos et al. 2014; Ignjatov et al. 2012; JinHyeuk et al. 2001) are being studied in this work. Power generators are increasingly being used in homes, offices, and production factories in Nigeria and the air in the surrounding environment is polluted by the fumes discharged from their exhausts.

\section{Methods}

The investigation was carried out in vitro on $R$. stolonifer and $F$. oxysporum isolated from diseased tomato fruits. Spore germination and germ tube growth of both fungi were studied. Suspensions of the spores of the fungi were prepared from 10-day-old cultures on malt extract agar, separately in sterile water. Two drops of spore suspension were placed on each of several microscope slides. The slides were separately exposed to emissions in a closed wooden chamber for $5-45 \mathrm{~min}$ at 5 -min intervals. The emissions were fumes from the exhaust of a power generator fed into the box through a rubber tube fitted tightly into a hole of $2.5-\mathrm{cm}$ diameter at the base of the box. The slides were thereafter incubated in a humid chamber at $28^{\circ} \mathrm{C}$. Incubation was for 16 and 24 $\mathrm{h}$, respectively, for $R$. stolonifer and $F$. oxysporum after which percentage germination was determined in ten different microscope fields on each slide under $\times 40$ objective of the light microscope. Spore germination was taken as protrusion of the cell wall beyond $1 \mu \mathrm{m}$. Mean percentage germination in the ten fields was calculated.
The slides were further incubated for $12 \mathrm{~h}$ and their total germ tube lengths were measured with ocular micrometer after calibration with stage micrometer under $\times 40$ objective of the microscope.

Kane portable auto 4-1 gas analyzer (01ML class 1 Pro kit-1SSWWW) was used to gage the amounts of carbon monoxide $(\mathrm{CO})$, carbon dioxide $\left(\mathrm{CO}_{2}\right)$, oxygen, and hydrocarbons in the exhaust fumes. This was done by inserting the probe of the analyzer into the generator exhaust pipe for 15- and 30-min periods while the generating set was running. The quality of emitted gasses was noted on the meter of the equipment. The emission applied had equivalent quantities of the gasses on Table 1.

\section{Results}

Exposure of spores to emissions initially resulted into increased germination percentage in $R$. stolonifer but as length of exposure increased, significant decrease in germination occurred up to $25 \mathrm{~min}$ then, a small insignificant increase occurred from 30 to 35 min (Fig. 1). After that, there was consistent reduction till $45 \mathrm{~min}$. There were two germination peaks observed, a distinct high one at $10 \mathrm{~min}$ and a less conspicuous small one at 30 $35 \mathrm{~min}$. Reduction in spore germination was by $5-25 \%$ in $R$. stolonifer while enhancement was by $\sim 100 \%$. Germ tube length of the fungus however initially reduced by $38 \%$ at 5 min exposure, it then increased by the 10th minute exposure, before a consistently significant reduction up till $25 \mathrm{~min}$. After that, the length fluctuated statistically insignificantly, though still significantly less than that of control. All exposure periods were statistically significantly different from the control being reduced by 24-76\% (Fig. 2).

For $F$. oxysporum spores, germination percentage reduced at $5 \mathrm{~min}$ exposure by $31 \%$ then increased at 10 min before consistently reducing till the 25 th minute. It then increased at $30 \mathrm{~min}$ by $10 \%$, before reduction again up to $40 \mathrm{~min}$ (Fig. 1). Results also showed two germination peaks at 10 and $30 \mathrm{~min}$. At 40-min exposure, germination was significantly different from that of control while other exposures were only slightly significantly different from control and not different from each other. Reduction was by $5-71 \%$. Germ tube length followed a similar trend as germination with length of exposure,

Table 1 Composition of gasses detected in gasoline emissions from power generator

\begin{tabular}{lll}
\hline Type of gas & \multicolumn{2}{l}{ Min of running generator/concentration of gas } \\
\cline { 2 - 3 } & 15 & 30 \\
\hline Carbon monoxide (\%) & 3.55 & 3.90 \\
Carbon dioxide (\%) & 4.40 & 5.20 \\
Oxygen (\%) & 0.00 & 0.00 \\
Hydrocarbons (ppm) & 0.2649 & 0.2499 \\
\hline
\end{tabular}




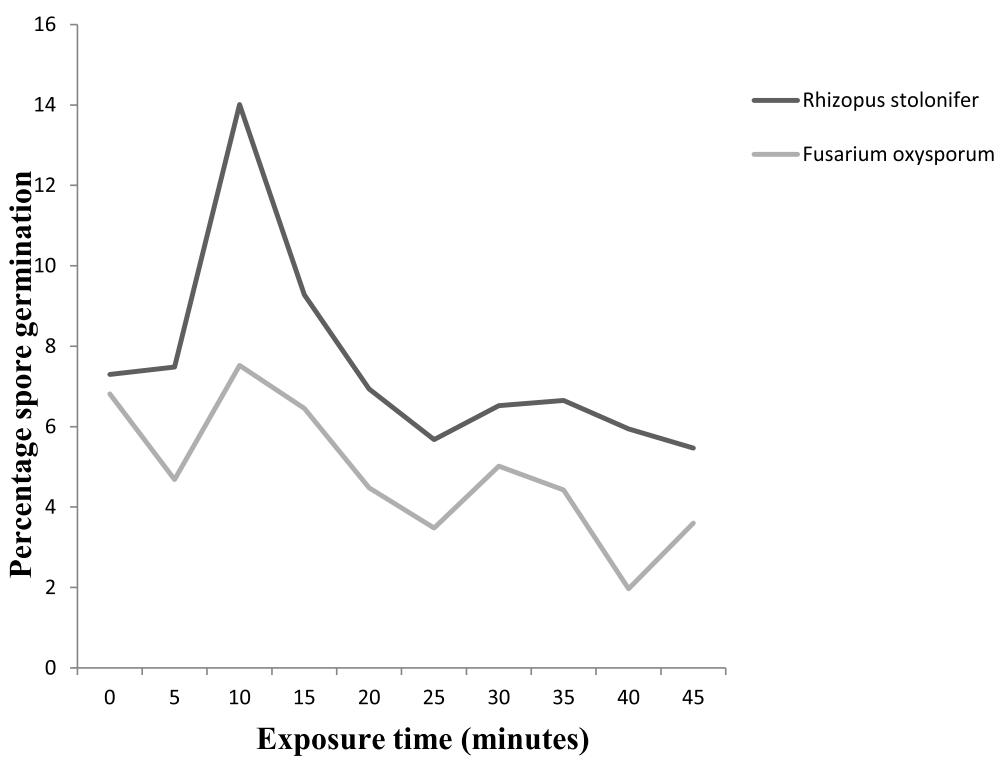

Fig. 1 Percentage germination of Rhizopus stolonifer and Fusarium oxysporum spores after exposure to gasoline emission and incubation at $28^{\circ} \mathrm{C}$

but there was a prominent peak at 30 min exposure which was less and not significantly different from the control (Fig. 2). There were also multiple peaks, a lower one at 10-20 min and a higher one at $30 \mathrm{~min}$ exposure but all lengths were less than that of the control though some were not significant. Reduction was by $5-83 \%$. At 40-min exposure, greatest reduction in germ tube length occurred and was significantly different from control (Fig.2).

The fumes from the generator had 0\% oxygen, increase in carbon monoxide concentration from 3.55 to $3.90 \%$, and carbon dioxide from 4.4 to $5.2 \%$, while hydrocarbons content reduced from 0.2649 to 0.2499 ppm at the 15- and 30-min testing periods (Table 1).

\section{Discussion}

Results from this study revealed that gasoline emissions lacking oxygen, low in hydrocarbons but high in carbon monoxide and carbon dioxide, negatively influenced growth of $R$. stolonifer and $F$. oxysporum although there was an initial stimulation of spore germination in $R$. stolonifer. Generally however, spore germination and germ tube lengths of $R$. stolonifer decreased with exposure. The greatest inhibitory effect of emissions observed at

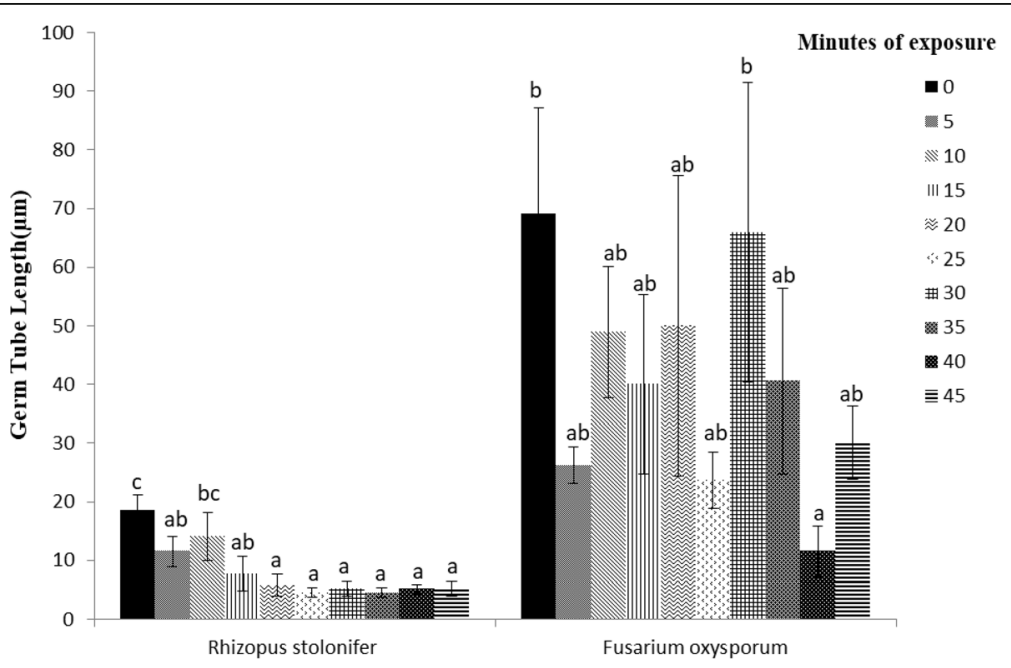

Fig. 2 Germ tube length of Rhizopus stolonifer and Fusarium oxysporum after exposure to gasoline emission and incubation at $28^{\circ} \mathrm{C}$ 
the highest exposure periods for the two fungi show the harmful effect of the emissions with prolonged exposure. This might have been due to the high concentration of carbon monoxide and carbon dioxide coupled with the complete absence of oxygen. $R$. stolonifer was reported to grow significantly at $0 \%$ oxygen but high concentrations of $\mathrm{CO}_{2}$ suppressed mycelium growth of the fungus (Wells and Uota 1969). On the contrary in another report, the spores of $R$. stolonifer did not germinate when molecular oxygen was rigorously excluded (Bussel et al. 1969). The initial stimulation observed in this study, may be due to the low levels of inhibitory oxides of carbon which the mold fungus was exposed to at the initial phase. The observed increase in levels of oxides of carbon with time of running the power generator supports this explanation. In addition, $R$. stolonifer being a fastergrowing fungus, may have initiated germination in the first few minutes of exposure before the first test at 5 min such that no negative effect was observed at that period of exposure. Germ tube emergence occurred in $F$. oxysporum from $4 \mathrm{~h}$ when grown on potato dextrose agar (Kumari et al. 1975), while for $R$. stolonifer , modeling experiments showed that evidences of germination were expected from $30 \mathrm{~s}$ at $25^{\circ} \mathrm{C}$ in water (Gabler et al. 2004). Longer exposures however had effect as the emitted gas constituents may have altered the chemical composition of the medium after dissolving in water to various extents.

Anaerobic environment, created by the absence of oxygen and elevated $\mathrm{CO}_{2}$ and $\mathrm{CO}$ levels may have led to anoxia within the fungal cells causing the yield of less metabolic energy (Atwell et al. 2015) and energy is needed for growth to take place. This likely inhibited fungal growth measured as spore germination and germ tube extension. Therefore, it was not unexpected that increase in $\mathrm{CO}$ and $\mathrm{CO}_{2}$ concentrations in the atmosphere inhibited growth of the two filamentous fungi tested. The oxides of sulfur and nitrogen which are also reported to be present in gasoline emissions (Tavares et al. 2010) though not detected by the equipment used in this study might have also formed acidic solutions in water causing direct and indirect inhibition of growth. Pure cultures of Cladosporium cladosporioides (Fres.) De Vries and Coniothyrium olivaceum Bonord were inhibited by sulfur dioxide $\left(\mathrm{SO}_{2}\right)$ concentrations of $<0.053 \mu \mathrm{l} / \mathrm{l}$ (Wookey et al. 1991). Concentration dependence of fungal pathogen response to $\mathrm{SO}_{2}$ revealed that high concentrations were suppressive, while low concentrations caused greater severity of fungal plant diseases (Khan and Khan 2011). There are inconsistent reports on the influence of nitrogen oxides on fungal growth (Depayras et al. 2018; Orr and Nelson 2018; Strohm et al. 2019).
The survival of the two fungi at such long exposure to gasoline emissions is indicative of their tolerance to the unfavorable environment. Despite exposure to emissions, the organisms may therefore still be active in growth for long periods. Their pathogenic abilities in vivo therefore need to be investigated. The oxides of carbon dissolve in water forming weak carbonic acid. The carbonic acid together with other acids formed by emitted oxides of nitrogen and sulfur in solution probably also contributed to inhibition of fungal growth measured as hyphal extension. This is because the acids formed must have lowered the $\mathrm{pH}$ of the medium. The varied effects of $\mathrm{pH}$ on growth of $F$. oxysporum have been reported (Gordon et al. 2019).

The hydrocarbons in gasoline detected in the emissions most likely also played a role in negatively influencing growth of fungi. The observed decrease in hydrocarbons level with length of running the power generator coinciding with the much higher level of growth in Fusarium than Rhizopus at the higher exposure periods signify that Fusarium thrived better at reduced hydrocarbons concentration even when the concentrations of carbon oxides increased. Aromatic hydrocarbons from marine gas oil (MGO) inhibited growth of soil fungi by stopping hyphal extension (Hughes et al. 2007). In this study, $R$. stolonifer however seemed more affected by $\mathrm{CO}_{2}, \mathrm{CO}$, and hydrocarbon levels of emissions. The consistent reduction in germination of $R$. stolonifer spores compared with fluctuations in that of $F$. oxysporum are evidences of the relative resistances of the fungi, with $R$. stolonifer appearing less susceptible to the negative effects of the emissions than $F$. oxysporum. The fact that the most effective inhibition of germ tube elongation of $R$. stolonifer occurred from $25 \mathrm{~min}$ exposure when hydrocarbon content had decreased confirms that all gasses in the emissions had more serious effect on the fungus, though the hydrocarbons might have exerted more effect. Fungi from gasoline polluted soils in liquid cultures showed favorable growth on volatile aromatic hydrocarbons in a combination of low $\mathrm{pH}$ and low water activity using the hydrocarbons as their sole carbon and energy sources (PrenafetaBoldu et al. 2001). The source of carbon in the present study was solely from the emissions which also lowered the $\mathrm{pH}$ of the liquid in which the fungi were suspended. It is probable that $R$. stolonifer and F. oxysporum employed the emissions for their carbon supply. More fungi isolated from air filters exposed to hydrocarbon-polluted gas streams assimilated volatile aromatic hydrocarbons for their carbon and energy requirements (Prenafeta-Boldu et al. 2006).

For $F$. oxysporum spores, the fluctuating germination percentage with length of exposure after an initial 
stimulation whereby two peaks of decreased height were observed however, demonstrate the ability of the fungus to adjust to unfavorable environment. Progressive decrease in microbial growth of Fusarium sp. occurred on PDA with increase in concentration of crude oil (Nwadinigwe and Obinwa 2006). Gasoline, itself from crude oil, probably played a role in negatively influencing growth of fungi in the present study. The initial reduction in germination and germ tube length of $F$. oxysporum suggest that the organism being slower growing than $R$. stolonifer was from the onset more affected by the unfavorable environment created by gasoline emissions. Thereafter, F. oxysporum physiologically adjusted and adapted, even though growth was inhibited in both fungi. F. oxysporum adjusted better to the unfavorable environment in its vegetative growth, so the fungus may survive longer than $R$. stolonifer especially as hyphal fragments, when gasoline emissions pollute the environment. This was evidenced by the longer germ tubes of $F$. oxysporum even at high exposure periods.

\section{Conclusions}

Generator emissions affected the growth of both fungi tested causing reductions. The aspect of growth more affected in $R$. stolonifer was the germ tube extension while for $F$. oxysporum spore germination was more affected. The multiple peaks observed with increasing length of exposure for spore germination and germ tube growth for both fungi are evidences of their attempt to adjust to the unfavorable environment created by gasoline emissions. Both organisms may likely survive such adverse conditions for long periods even though their growth may decrease significantly. Exposure of infected plants to gasoline generator fumes may therefore play a role in alleviating fungal disease severity.

\section{Acknowledgements}

Not applicable

\section{Availability of supporting data and materials}

All data generated or analyzed during the study are included in this published article.

\section{Authors' contributions}

The data was collected and statistically analyzed by KPB. The manuscript was prepared by AAT who also supervised the laboratory work, while all authors including $\mathrm{OOO}$ read and approved the manuscript. BKP's contribution was $40 \%$, ATA contributed $40 \%$ while 000 contributed $20 \%$ to the work.

\section{Authors' information}

KPB is a graduate student of Environmental Biology while ATA and OOO hold positions as lecturers in biology with interest in postharvest pathology/ mycology. Both AAT and $\mathrm{OOO}$ are members of the Mycological Society of Nigeria.

\section{Funding}

Not applicable

Ethics approval and consent to participate Not applicable
Consent for publication

Not applicable

\section{Competing interests}

Not applicable

Received: 19 May 2020 Accepted: 23 August 2020

Published online: 04 September 2020

\section{References}

Aliyu YA, Botai JO, Abubakar AZ, Youngu TT, Sule JO, Shebe MW, Bichi MA (2019) Atmospheric air pollution in Nigeria: a correlation between vehicular traffic and criteria pollutant levels. In: Labour AAL (ed) Atmospheric air pollution and monitoring. https://doi.org/10.5772/intechopen.86554

Atwell BJ, Greenway H, Colmer TD (2015) Efficient use of energy in anoxia - tolerant plants with focus on germination rice seedlings. New Phytol 206(1):36-56

Bautista-Banos S, Bosquez-Molina E, Barrera-Necha LL (2014) Rhizopus stolonifer soft rot. In: Bautista-Banos S (ed) Postharvest decay - control strategies, vol 2014. Elsevier Publ, pp 1-44. https://doi.org/10.1016/B978-0-12\%2D\% 2D411552-1-00001-6

Bussel J, Sommer NF, Kosuge T (1969) Effect of anastomosis upon germination and survival of Rhizopus stolonifer sporangiospores. In AGRIS 2013:946-952 agris.fao.org

Darrall NM (2006) The effect of air pollutants on physiological processes in plants Plant Cell Environ 12(1):1-30

Depayras S, Kondakova T, Heipieper HJ, Feuilloley MGJ, Orange N, Duclairoir-Poc C (2018) The hidden face of nitrogen oxides species: from toxic effects to potential cure? https://doi.org/10.5772/intechopen.75822

Fagbeja MA, Chatterton TJ, Longhurst JWS, Akinyede JO, Adegoke JO (2008) Air pollution and management in the Niger Delta - emerging issues. Trans Ecology Environ 116:207-216. https://doi.org/10.2495/AIR080221

Gabler FM, Mansour MF, Smilanick JL, Mackey BE (2004) Survival of spores of Rhizopus stolonifer, Aspergillus niger, Botntis cinerea and Alternaria altternata after exposure to ethanol solutions at various temperatures. J Appl Microbiol 96:1354-1360

Gordon TR, Stueven M, Pastrana AM, Henry PM, Dennehy CM, Kirkpatrick SC, Daugovish O (2019) The effect of pH on spore germination, growth and infection of strawberry roots by Fusarium oxsporum f.sp. Catharine cause of Fusarium wilt of strawberry. Plant Dis 103(4):697-704

Hughes R, Bridge P, Clark MS (2007) Tolerance of Antarctic soil fungi to hydrocarbons. Sci Total Environ 372(2-3):539-548

Ignjatov M, Milosevic D, Nikolic Z, Gvozdanovic-Varga J, Jovicic D, Zdjelar G (2012) Fusarium oxsporum as causal agent of tomato wilt and fruit rot. Pesticide Phytomed 27(1):25-31

Jin-Hyeuk K, Soo-Woong K, Jeong-Soo K, Chang-Seuk P (2001) Rhizopus soft rot on Cherry tomato caused by Rhizopus stolonifer in Korea. Mycobiol 29(3):176178. https://doi.org/10.1080/12298093.2001.12015783

Khan MR, Khan MM (2011) Plant response to diseases in sulphur dioxide stressed environment. Plant Pathology J 10(1):1-12

Kumari L, Decallonne JR, Meyer JA (1975) Deoxyribonucleic acid metabolism and nuclear division during spore germination in Fusarium oxysporum. J Gen Microbiol 88:245-252

Marais EA, Jacob DJ, Wecht K, Lerot C, Zhang L, Yu K, Kurosu TP, Chance K, Sauvage B (2014) Anthropogenic emissions in Nigeria and implications for atmospheric ozone pollution: a view from space. Atmos Environ 99:32-40

Nwadinigwe Al, Obinwa KN (2006) Effects of crude oil on the fungus that attacks groundnut. J Res Bioscience 2(1):14-18

Orr R, Nelson PN (2018) Impact of soil abiotic attributes on Fusarium wilt, focusing on bananas. Applied Soil Ecology 132:20-33

Osuji LC, Awwiri GO (2005) Flared gases and other pollutants associated with air quality in industrial areas of Nigeria: an overview. Chem Biodivers 2(10):1277-1289

Prenafeta-Boldu FX, Kuhn A, Luykx DMAM, Anke H, van Groenestijn JW, de Bant JAM (2001) Isolation and characterization of fungi growing on volatile aromatic hydrocarbons as their sole carbon and energy source. Mycol Res 105(4):477-484

Prenafeta-Boldu FX, Summerbell R, de Hoog GS (2006) Fungi growing on aromatic hydrocarbons: biotechnology's unexpected encounter with biohazard. FEMS Microbiol Rev 30(1):109-130

Strohm E, Herzner G, Ruther J, Kaltenpoth M, Engl T (2019) Nitric oxide radicals are emitted by wasp eggs to kill mold fungi. https://doi.org/10.7554/eLife.43718 
Tavares JR, Sthel MS, Campos LS, Rocha MV, Lima GR, da Silva MG, Vargas G

(2010) Evaluation of pollutant gases emitted by ethanol and gasoline powered vehicles. Proc Environ Sci 4:51-60

Wells JM, Uota M (1969) Germination and growth of five fungi in low-oxygen and high carbon- dioxide atmospheres. Phytopathology 60:50-53

Winner WE, Greitner CS (2000) Field methods used for air pollution research with plants. In: Pearcy RW, Ehleringer JR, Mooney HA, Russell PW (eds) Plant physiological ecology. Springer, Dordrecht, pp 399-425. https://doi.org/10. 1007/978-94-010-9013-1_17

Wookey PA, Ineson P, Mansfield TA (1991) Effects of atmospheric sulphur dioxide on microbial activity in decomposing forest litter. Agric Ecosyst Environ 33(3): 263-280. https://doi.org/10.1026/0167.8809(91)90006-J

\section{Publisher's Note}

Springer Nature remains neutral with regard to jurisdictional claims in published maps and institutional affiliations.

\section{Submit your manuscript to a SpringerOpen ${ }^{\circ}$ journal and benefit from:}

- Convenient online submission

- Rigorous peer review

- Open access: articles freely available online

- High visibility within the field

- Retaining the copyright to your article

Submit your next manuscript at $\boldsymbol{\wedge}$ springeropen.com 